\title{
Conners Anababa Dereceleme Ölçeği-Yenilenmiş Kısa: Türkiye Stardardizasyon Çalışması
}

\section{Conners Parent Rating Scale-Revised Short: Turkish Standardization Study}

\author{
Sema KANER1, Şener BÜYÜKÖZTÜRK2, Elvan IŞER|2 \\ 1Ankara Üniversitesi, Eğitim Bilimleri, Ankara, Türkiye \\ 2Gazi Üniversitesi, Eğitim Bilimleri, Ankara, Türkiye
}

\section{ÖZET}

Amaç: Araştırmanın amacı, Conners Anababa Dereceleme Ölçeği-Yenilenmiş Kısa (CADÖ-YK) formunun Türkiye için uyarlama çalışmasını yapmaktır.

Yöntem: Araştırmaya, Türkiye'nin yedi ilinden seçilen 6-17 yaşları arasındaki 2736 çocuğun anababaları katılımışlardır. CADÖ-YK'nın yapı geçerliği Doğrulayıcı Faktör Analiziyle (DFA) ve alt ölçekler arası korelasyonların hesaplanması yoluyla incelenmiștir. Yine yapı geçerliğini test etmek için benzer yapıları ölcctüğü düşünülen Conners Anababa Dereceleme Ölçeği-Y̌enilenmiş Uzun (CADÖ-YU), Conners Anababa Dereceleme Ölçeği-48, Conners Öğretmen Dereceleme ÖlçeğiYenilenmiş Kısa (CÖDÖ-YK), Conners-Wells Ergen Öz-Bildirim Ölçeği-Yenilenmiş Kısa (C-WEÖÖ-YK), Yenilenmiş Problem Davranış Kontrol Listesi (YPDKL) kullanılmıştır. Ayrıca, madde analzi de yapılmıştır. CADÖ-YK formunun alt ölçeklerinin iç tutarlılı̆̆ ve 8 hafta arayla test-tekrar test güvenirliği incelenmiştir. Bulgular: DFA sonuçları, CADÖ-YK formunun özgün yapısının Türk toplumu için de geçerli olduğunu ortaya koymuştur. Alt ölçekler arası korelasyonlar orta düzeydedir. CADÖ-YK formunun CADÖ-YU, CÖDÖ-YK, C-WEÖÖ-YK, CADÖ-48, YPDKL ile ilișkilerinin düșükten orta düzeye doğru değiștĭgi; ölçeğin alt ve üst $\% 27$ 'lik grupları birbirinden ayırt ettiği bulunmuştur. CADÖ-YK formunun alt ölçeklerinin Cronbach alfa ve iki yarı güvenirlik katsayıları sırasıyla 0,73-0,86 ve $0,72-0,85$ arasında değişmektedir. Ölçeğin alt ölçeklerinin test-tekrar test güvenirlik değerleri ise 0,56-0,72'dir.

Sonuç: Analiz sonuçları, CADÖ-YK'dan elde edilen puanların geçerlik ve güvenirliğinin tatmin edici düzeyde olduğunu göstermektedir. (Nöropsikiyatri Arşivi 2013; 50: 100-109)

Anahtar kelimeler: CADÖ-YK, faktör analizi, geçerlik, güvenirlik

Çıkar çatışması: Yazarlar bu makale ile ilgili olarak herhangi bir çıkar çatışması bildirmemişlerdir.

\begin{abstract}
Background: The aim of this study was to adapt the Conners's Parent Rating Scale-Revised Short form (CPRS-RS) to Turkish population.

Methods: Parents of 2736 children aged 6-17 from 7 cities in Turkey were included in the study. Construct validity of the CPRS-RS was tested by Confirmatory Factor Analysis (CFA) and intercorrelations between the subscales. Besides, the Conners' Parent Rating Scales-Revised Long version (CPRS-RL), Conners' Parent Rating Scales-48 (CPRS-48), Conners' Teacher Rating Scales-Revised Short (CTRS-RS), Conners-Wells' Adolescent Self-Report-Revised Short form (CASSRS), and the Revised Problem Behavior Checklist (RPBCL), which measures the same structures as CPRS-RS, were used to assess validity of the scale. In addition, item analysis was conducted. Internal reliability and test-retest reliability at a 8 week interval were calculated for the CPRS-RS' subscales.

Results: Results of CFA suggested that the original form of the CPRS-RS was valid for the Turkish community. Correlations between the subscales were moderate. Relationship of CPRS-RS with CTRS-RS, CASS-RS and RPBCL were low to moderate; CPRS-RS discriminates groups of upper $27 \%$ and lower $27 \%$ significantly. Cronbach alpha and split-half reliability coefficients of the subscales were between 0.73 and 0.86 and 0.72 and 0.85 , respectively. Test-retest reliability coefficients of the subscales were between 0.56 and 0.72 .

Conclusion: The psychometric properties of the Turkish version of the CPRS-RS were quite adequate. (Archives of Neuropsychiatry 2013; 50: 100-109)

Key words: CPRS-RS, factor analysis, validity, reliability
\end{abstract}

Conflict of interest: The authors reported no conflict of interest related to this article.

\section{Giriş}

Dikkat Eksikliği ve Hiperaktivite Bozukluğu (DEHB), okul çağı çocuklarında sıklıkla rastlanan problem alanlarından biridir. Çocukluk döneminde DEHB'nun \%3-10 arasında görüldüğü bildirilmektedir $(1,2,3,4)$. Zamanında tanı koyulmadığı ve uygun tedavi ve eğitim hizmetleri düzenlenmediği takdirde, okulda, evde ve diğer sosyal ortamlarda pek çok işlev bozukluklarına yol açarak bireyin yaşamını güçleştiren önemli bir soruna dönüştüğü gözlenmektedir. Bu nedenle, erken tanı ve erken müdahale 
hizmetleri, DEHB'nun olumsuz etkilerinin azaltılmasında çok önem taşımaktadır. Müdahalenin etkili olabilmesi için, ilgili sorunların etkili şekilde değerlendirilebilmesi gereklidir.

DEHB'nun değerlendirilmesinde çoklu yaklaşımlar kullanılmaktadır. Tanı, DSM-IV gibi standart tanı ölçütlerine göre koyulmaktadır (5). DSM-IV'ün yanı sıra, görüşme, gözlem ve dereceleme ölçekleri gibi tanı koymaya yardımcı diğer yöntemlerden de sıkıkla yararlanılmaktadır. Özellikle ayrıntılı klinik değerlendirmenin yapılamadığı durumlarda, büyük gruplarda tedavi ve eğitim hizmetlerine gereksinimleri olan bireyleri belirlemek için dereceleme ölçekleri çok yararlı araçlardır. Dereceleme ölçekleri yoluyla anababa, öğretmen, akran ve bireyin kendisi gibi farklı bilgi kaynaklarından bireyle ilgili önemli bilgiler elde edilebilmektedir.

DEHB'nu değerlendirmek amacıyla geliştirilmiş pek çok araç bulunmaktadır. Conners'ın dereceleme ölçekleri bunlar arasında en tanınmış ve en çok kullanılan araçlardan biridir. Conners, çocuk ve ergenlerde, öncelikle DEHB olmak üzere çeşitli sorun davranışları belirlemede klinik tanıya yardımcı olmak, uygulanan tedavinin ve/veya eğitimin etkilerini belirlemek amacıyla bir dizi ölçme aracı geliştirmiştir $(6,7,8,9,10)$.

Conners'ın ölçekleri 1960 'lardan beri yapılan ampirik çalışmaların sonucudur. Conners dereceleme ölçeklerinin son sürümleri, DEHB'nun yanı sıra, çocukluk ve ergenlikteki diğer sorun davranışların değerlendirilmesinde de standart bir ölçme yapmaktadır. Anababa, öğretmen ve ergen kombinasyonu ise çocukla ilgili elde edilen bilgilere zenginlik getirmektedir $(7,8,9,10,11,12)$. Conners ölçeklerinin son sürümleri olan Conners Anababa Dereceleme Ölçeği, Conners Öğretmen Dereceleme Ölçeği, Conners-Wells Ergen Özbildirim Ölçeği'nin uzun ve kısa formları da bulunmaktadır. Bu çalışmada Conners Anababa Dereceleme Ölçeğinin (CADÖ) kısa formunun Türk çocuklarının anababalarından toplanan veriler ile uyumu incelenecektir.

Conners Anababa Dereceleme Ölçeği Yenilenmiş Kısa (CADÖYK), DEHB'nun yaygınlığının belirlenmesinde ve tanı koyulmasında $(13,14,15,16)$, tedavinin ve eğitimin etkisinin değerlendirilmesinde $(17,18,19,20,21,22,23)$ yaygın olarak kullanılmaktadır. Yeni sürümüyle ilgili çalışmalar A.B.D. ve Kanada'da yapılmıştır $(7,8,9,10,24,25)$. Bunun dişında CADÖ-YK, Almanya $(22,26)$, Avustralya (20), Çin $(14,27)$, Ingiltere (13), İsviçre $(15)$, İspanya $(18,28)$, Küba $(29)$ ve Malezya (30) gibi farklı kültürlerde kullanılmıștı. Ancak, bu çalışmaların çoğunda ölçeğin o kültür için psikometrik özellikleri hakkında yeterli bilgi sunulduğu söylenemez. İspanyolca uyarlama çalışmasıyla ilgili bilgilerin ayrıntısına ise ulaşılamamışıı (31).

Türkiye'de şu anda Conners'ın ölçeklerinin eski sürümlerinden olan Conners Anababa Dereceleme Ölçeği-48 (CADÖ-48) ve Conners Öğretmen Dereceleme Ölçeği-28 (CÖDÖ28) kullanılmaktadır. CADÖ-48'in ve CÖDÖ-28'nin Türkiye'ye uyarlama çalışmaları Dereboy ve arkadaşları tarafından yapılmıştır $(32,33,34,35,36)$. Ancak, bu uyarlama çalışmaları, hedef kitle ve örneklem olarak sadece Ankara ili ile sınırıdır ve normları oluşturulmamıştır. Eski formların psikometrik özelliklerinin farklı olması, uygulamacıların ve araştırmacıların anababa ya da öğretmen formlarından birini kullanmaya itmekteydi. Yenilenmiş formlar ise normlarının gücü, güvenirlik ve geçerlik özellikleri açısından birbiriyle neredeyse özdeştirler. Öğretmen ve ana- baba kısa formları, anababalar ve öğretmenler arasında kıyaslama yapılabilmesini kolaylaştırmak amacıyla aynı alt ölçeklerden oluşmaktadır (7).

Anababa ve öğretmen ölçeklerinin önceki sürümleri pek çok araşıırmada ve klinik ortamlarda yaygın olarak kullanılmasına, yüksek güvenirlik ve geçerlik değerlerine rağmen, bazı nedenlerle ölçeklerin yeniden standardizasyon çalışmalarına gerek duyulmuştur. Conners ve arkadaşları $(7,9,10)$ bu gerekçeleri şu șekilde açıklamaktadırlar: 1) halihazırda kullanılan normlara ilişkin verilerin nispeten küçük bir örneklemden elde edilmiş olması ve bu örneklemin büyüklüğünün, coğrafik özelliklerinin ve demografik özelliklerinin ölçeklerin kullanıldı̆̆ı geniş çeşitlilikteki çocukları temsil edici olmaması, 2) pek çok çalışmada ölçeklerin farklı faktör yapıları vermesi, 3) ölçeklerdeki maddeler çocukluk dönemindeki davranışları değerlendirmek amacıyla geliştirilmesine rağmen, bu maddelerin çoğunun karşılaşılan en yaygın problem davranışlarla ilişkili olmaması, 4) ölçeklerin, kaygı ve depresyon gibi içe yönelim (internalizing) problemlerini yeterince temsil etmemesi, 5) maddelerin, davranış bozukluklarıyla ilgili yeni bilgiler doğrultusunda güncelleștirilmemiş olması. Bu gerekçelerle, büyük ve temsil edici bir örneklemden normatif verileri elde etmek, tanımlayıcı bir faktör yapısını oluşturmak, DEHB ie ilgili davranışları doğrudan belirleyecek ölçekler oluşturarak geçerlik ve güvenirliklerini belirlemek ve günümüz bilgileri doğrultusunda maddeleri güncelleştirmek amacıyla ölçekleri yenileme çalışmaları yapılmışıı (7).

Conners'ın bu gerekçeleri dikkate alınarak, bu çalışmada Conners'ın yenilediği ölçekler arasından Anababa Dereceleme Ölçeğinin Kısa formunun, Türk çocuklarının anababalarından toplanacak veriler ile ne derece uyumlu olduğu incelenecektir.

\section{Yöntem}

\section{Örneklem}

Araştırmanın evreni, Türkiye'de 6-17 yaş arası çocukların ve gençlerin anababalarıdır. Bu çocukların/gençlerin problem alanlarına ilişkin veri toplamak ve gözlem birimi olan anababalara ulaşmak amacıyla Türkiye'nin dört coğrafik bölgesinden (İç Anadolu, Doğu Anadolu, Karadeniz, Marmara) rastgele seçilen 7 il (Ankara, Bolu, Çorum, Giresun, Iğdır, Kırıkkale, Konya) araştırma kapsamına alınmıştır. Bölgelerin ve illerin seçilmesinde araştırmacıların olanakları belirleyici olmuştur. Her bir ilde farklı sosyoekonomik çevrelerden olmak üzere düz ilköğretim okullarından ve liselerinden ikişer okul belirlenmiştir. Illerde örnekleme alınacak okulların sosyo-ekonomik çevrelerinin değerlendirilmesinde uygulamayı gerçekleştirecek olan rehber öğretmenlerin görüşleri temel alınmıştır. Araçların uygulanmasında gönüllülük ilkesi benimsenmiş̧ir. İlköğretim okullarından ve liselerden her sınıftan birer şube okul yönetimlerince yansız olarak seçilmiştir. Daha sonra, öğrenci seçiminde yanllığı önlemek amacıyla seçilen şubelerin öğrenci listelerinin ilk beşi ile son beşinde yer alan çocukların anababaları, gözlem birimi olarak ulaşılan örneklemi oluşturmuştur.

CADÖ-YK formunu anneler $(n=1318, \% 48,2)$, babalar $(n=1099$, $\% 40,2)$, anne ve baba birlikte $(n=49, \% 1,8)$, anne ya da babanın yerini tutan kişiler ( $n=94, \% 3,4)$ ve kimliği belirtilmemiş kişiler ( $n=176, \% 6,4)$ yanıtlamışlardır. 
Araştırmada problem alanları için anababalarından veri toplanan öğrenci sayısı 2736'dır. Öğrencilerin \%59,0'u (n=1614) kız, $\% 41,0^{\prime} i$ (n=1122) erkektir. Tüm grubun yaş ortalaması $12,83^{\prime}$ dür (SS=2,99). Tablo 1'de anababaların değerlendirdikleri çocukların yaş ve cinsiyetlerine göre dağılımları verilmiş̧tir.

\section{Veri Toplama Araçları}

Conners Anababa Dereceleme Ölçeği-Yenilenmiş Kısa (CADÖYK)-Conners Parent Rating Scale-Revised Short (CPRS-RS). CADÖ-YK, Conners (7) tarafından, yenilenmiş uzun formlar için toplanan verilere uygulanan açımlayıcı faktör analizi sonucunda en yüksek faktör yükü veren maddelerin seçilmesi ile oluşturulmuştur. CADÖ-YK, 27 maddeden oluşmaktadır. Maddeler, üç alt ölçekte (Karşı Gelme-KG, Bilişsel Problemler-DikkatsizlikBP-D, Hiperaktivite-H) ve bir yardımcı ölçekte (DEHB İndeksiDEHB) toplanmıştır.

Puanlama. Her madde için puan değeri 0-3 arasında değişen 4 yanıt seçeneği vardır. Hiçbir zaman doğru değil (hiçbir zaman, çok ender), 0 puan; biraz doğru (bazen), 1 puan; oldukça doğru (sık sık, oldukça çok), 2 puan; çok doğru (çok sık), 3 puan. Yüksek puan, çocuğun CADÖ-YK'da tanımlanan problemlere o kadar çok sahip olduğunu göstermektedir.

Araştırmada CADÖ-YU formunun geçerliğini değerlendirmek amacıyla aşağıdaki ölçme araçları kullanılmıştır.

Conners Anababa Dereceleme Ölçeği-Yenilenmiş Uzun (CADÖYU)-Conners' Parent Rating Scale-Revised Long (CPRS-RL). Conners ve arkadaşları $(7,9)$ tarafından geliştirilen CADÖ-YU yedi alt ölçekten oluşmaktadır: Bilişsel Problemler-Dikkatsizlik (BP-D), Karşı Gelme $(K G)$, Hiperaktivite (H), Kaygı-Utangaçlık (KU), Mükemmelliyetçilik (M), Sosyal Problemler (SP) ve Psikosomatik (P). Bu alt ölçeklerin yanı sıra DSM-IV tanı ölçütlerini içeren DSM-IV İndeksi, yine DSMIV ölçütlerine göre DEHB'nu belirlemeye yönelik DEHB İndeksi ve Global İndeks de yardımcı araçlar olarak kullanılmaktadır.

Uzun formun Türkiye standardizasyon çalışması Kaner ve arkadaşları tarafından yapılmıştır $(37,38)$. Doğrulayıcı faktör analizi (DFA), CADÖ-YU'un Türk çocuklarından elde edilen yapısının özgün ölçek ile özdeş olduğunu göstermiştir (RMSEA:0.04, RMR:0.04, GFI:0.90, AGFI:0.89). CADÖ-YU'un Conners Anababa Dereceleme Ölçeği-48 ve Yenilenmiş Problem Davranış Kontrol Listesi ile ilişkilerinin orta düzeyde olduğu; ölçeğin tanısı olan ve olmayan grupları genel olarak ayırt ettiği bulunmuştur. Cronbach alfa ve iki yarı güvenirlik katsayıları sırasıyla $0,85-0,55$ ve $0,80-0,50$ arasındadır. Test-tekrar test güvenirlik değerleri ise $0,73-0,35$ 'dir.

Conners Öğretmen Dereceleme Ölçeği-Yenilenmiş Kısa (CÖDÖYK)-Conners' Teacher Rating Scale-Revised Short (CTRS-RS).
Conners tarafından geliştirilen ve 17 maddeden oluşan yenilenmiş öğretmen kısa formunda da yenilenmiş anababa kısa formdaki alt ölçekler bulunmaktadır (7): Karşı Gelme (KG), Bilişsel ProblemlerDikkatsizlik (BP-D), Hiperaktivite (H) ve DEHB İndeksi (DEHB). CÖDÖ-YK'da, tıpkı CADÖ-YK'da olduğu gibi yenilenmiş uzun öğretmen formunda faktör yükü en yüksek olan maddelerin seçilmesiyle oluşturulmuştur. Puanlaması, CADÖ-YK'daki gibidir.

Kısa formun Türkiye uyarlama çalışması Kaner ve arkadaşları tarafından yapılmıştır (39). Doğrulayıcı faktör analizi, CÖDÖ-YK'nın özgün yapısını Türk kültüründe de koruduğunu göstermiştir RMSEA:0.06, RMR:0.04, GFI:0.94, AGFI:0.92, CFI:0.99, NFI:0.98). Cronbach alfa katsayıları 0,86 ile 0,93; test-tekrar test katsayıları ise $0,77-0,87(p<0,0001)$ arasındadır.

Conners-Wells Ergen Öz-Bildirim Ölçeği-Yenilenmiş Kısa (C-WEÖÖ-YK)-Conners-Wells Adolescent Self-Report ScaleRevised Short (CASS-RS). Ergenlerdeki davranım bozukluklarını, dürtü kontrolsüzlüğünü, dikkat eksikliği, hiperaktive sorunlarını ve DEHB belirtilerini değerlendirmeyi amaçlayan C-WEÖÖ-YK, 12-17 yaş arasındaki gençlerin kendileriyle ilgili görüşlerini son bir aya göre değerlendirmelerine dayalıdır. Conners (7), C-WEÖÖ-YK'yı, kısa anababa ve öğretmen formlarında olduğu gibi uzun formdan türetmiştir. Bu form üç alt ölçekten oluşmaktadır: 1. Davranım Bozukluğu (DB), 2. Bilişsel Problemler-Dikkatsizlik (BP-D), 3. Hiperaktivite (H). C-WEÖÖ-YK, DEHB riski altında olan çocukları ve ergenleri değerlendiren bir yardımcı ölçek olan Dikkat Eksikliği Hiperaktivite İndeksi'ni de (DEHB) içermektedir. Puanlaması anababa ve öğretmen formunda olduğu gibidir.

C-WEÖÖ-YK'nın Türkiye için uyarlama çalışması Kaner ve arkadaşları tarafından yapılmıştır (40). DFA sonucunda Türk çocukları için özgün yapının korunduğu bulunmuştur (RMSEA=0,05, $\mathrm{RMR}=0,04, \mathrm{GFI}=0,95, \mathrm{AGFl}=0,94, \mathrm{NFI}=0,94, \mathrm{NNFI}=0,93, \mathrm{CFI}=0,94)$. C-WEÖ-YK için hesaplanan Cronbach alfa katsayıları 0,60-0,74, test güvenirlik katsayıları 0,74-0,80 arasında değişmektedir.

Conners Anababa Dereceleme Ölçeği-48 (CADÖ-48)-Conners' Parent Rating Scale-48 (CPRS-48). CADÖ-48, adından da anlaşılacağı gibi 48 maddeden ve beş alt ölçekten (Davranım Sorunları-DS, Ataklık-Hiperaktivite (A-H), Öğrenme Sorunları (ÖS), Kaygı (K) ve Psikosomatik (P) oluşmaktadır. Ölçekteki ifadelere dörtlü likert tipi bir ölçek üzerinden yanıt verilmektedir. Cevap seçenekleri ve puanlama şöyledir: Hiçbir zaman, 0 puan; nadiren, 1 puan; sıklıkla, 2 puan; her zaman, 3 puan. Yüksek puan, belirtilerin yoğun olduğunu ifade etmektedir.

CADÖ-48'in dilimize uyarlama çalışmaları Şener ve arkadaşları tarafından yapılmıştır. Ülkemizdeki analizler sonucunda AtaklıkHiperaktivite dışında özgün çalışmadan elde edilen faktörler

Tablo 1. Öğrencilerin yaş ve cinsiyetlerine göre dağılımları

\begin{tabular}{|c|c|c|c|c|c|c|}
\hline \multirow[t]{2}{*}{ Yaş } & \multicolumn{2}{|c|}{ KIz } & \multicolumn{2}{|c|}{ Erkek } & \multicolumn{2}{|c|}{ Toplam } \\
\hline & $n$ & $\%$ & $n$ & $\%$ & $\mathrm{n}$ & $\%$ \\
\hline $6-8$ & 153 & 47,1 & 172 & 52,9 & 325 & 11,9 \\
\hline $9-11$ & 251 & 48,6 & 265 & 51,4 & 516 & 18,9 \\
\hline $12-14$ & 425 & 53,7 & 367 & 46,3 & 792 & 28,9 \\
\hline $15-17$ & 785 & 71,2 & 318 & 28,8 & 1103 & 40,3 \\
\hline Toplam & 1614 & 59,0 & 1122 & 41,0 & 2736 & 100,0 \\
\hline
\end{tabular}


benzerlik gösterse de içerikleri tam uyuşmamış ve Öğrenme Sorunları ve Davranım Sorunları alt ölçeklerinin uyarlanması gerekmiştir (34,35). Analizler sonucunda Dikkat Eksikliği, Hiperaktivite, karşı Gelme ve Davranım Bozukluğu olmak üzere dört alt ölçek elde edilmiştir. Alt ölçeklerin Cronbach alfa katsayıları 0,67 ile 0,92 arasında değişmektedir. Madde-toplam korelasyonları ise 0,35-0,81 arasindadır (34).

Yenilenmiş Problem Davranış Kontrol Listesi (YPDK)-Revised Problem Behavior Checklist (RPBC): Quay ve Peterson (41) tarafından çocuklardaki/gençlerdeki problem davranışları belirlemek amacıyla geliștirilmiş olan YPDK, anababa ve öğretmen gibi çocuğa bakım veren ve/veya onu yakından tanıyan kişilerin görüşlerine dayalıdır. Altı faktörden (Davranım Bozukluğu-DB, Dikkat Problemleri-Toyluk-DP-T, Kaygı-Geri ÇekilmeK-GC, Toplumsallaşmış Saldırganlık-TS, Motor Gerilim-MG ve Psikotik Davranış-PD) ve 89 maddeden oluşmaktadır.

Türkiye'de Kaner ve arkadaşları tarafından YPDK için bir dizi uyarlama çalışması yapılmıştır $(42,43,44)$. Son uyarlama çalışmasında 5-17 yaş arasındaki çocukların ve ergenlerin öğretmenlerinden $(n=4818)$ ve anne-babalarından $(n=3849)$ olmak üzere, toplam 8667 kişiden elde edilen verilere DFA uygulanmıștır. DFA sonrasında bazı maddeler elenmiş ancak ölçeğin Türkçe formunda, özgün yapıdaki altı faktörün korunduğu gözlenmiştir. DFA sonucunda elde edilen uyum indeks değerleri $\mathrm{RMSEA}=0,085$; $\mathrm{RMR}=0,067 ; \mathrm{GFI}=0,70 ; \mathrm{AGFl}=0,68 ; \mathrm{NFI}=0,97 ; \mathrm{NNFI}=0,97 ; \mathrm{CFI}=097 ;$ IFI= 0,97'dir. YPDKL'nin Cronbach Alfa iç tutarlılık katsayıları 0.930,73 arasında değişmektedir.

YPDKL'ndeki maddeler üçlü likert tipi bir ölçek üzerinden değerlendirilmektedir $(0=$ problem değil, $1=$ orta derecede problem, $2=$ =ă̆ır derecede problem). YPDKL'den yüksek puan almak, problem davranışların yoğunluğunu ifade etmektedir.

Özgün CADÖ-YK'nın Türkçeleștirme İșlemi. Kısa form, uzun formdaki maddelerden seçilmiş olduğu için CADÖ-YU için yapılan Türkçeleștirme süreci sonucunda elde edilen metinden yararlanılmışıtır. Uzun form ile ilgili çalışmada orijinal dile (İngilizce) ve hedef dile (Türkçe) hakim, biri ölçme ve değerlendirme uzmanı, biri dil uzmanı, diğerleri de eğitimin ve psikolojinin çeşitli alanlarında çalışan profesyonellerden oluşan bir ekip tarafından maddeler Türkçe'ye çevrilmiştir. Daha sonra elde edilen ortak metin, iki uzman tarafından yeniden İngilizce'ye çevrilip orijinal metin ile tutarlı̆ı̆ı incelenmiş ve dil açısından ölçeklerin son durumu elde edilmiştir.

\section{İșlem}

Her sınıfın yoklama listesinden seçilen ilk beş ve son beş, toplam 10 öğrenci, anababaları tarafından Conners Anababa Dereceleme Ölçeği Yenilenmiş Kısa formu kullanılarak değerlendirmişlerdir. Bu amaçla, ölçme araçları anababalara iletilmek üzere okul yönetimlerince kapalı zarflar içerisinde rehber öğretmenlere teslim edilmiş ve aynı yolla kapalı zarflar içerisinde geri toplanmıştır. Rehber öğretmenler, ilkokul düzeyinde okumayazması olan ve okuduğunu anlayan anababalara CADÖ-YK formunun uygulanmasını sağlamışlardır. Anababaların ölçme aracını yanıtlamaları yaklaşık 5-10 dakika almıştır.

Toplanan araçlardan hatalı ve eksik yanıtlanmış olanlar elendikten sonra, kalan araçlardaki veriler bilgisayar ortamına aktarılmış ve geçerlik ve güvenirlik çalışmaları için aşağıda açıklanan analizler yürütülmüştür.

\section{Verilerin Analizi}

CADÖ-YK'nın üç faktörden oluşan özgün faktör yapısının Türk kültüründe ne derece geçerli olduğu Doğrulayıcı Faktör AnaliziDFA ile incelenmiştir. DFA'da, değişkenler arasındaki ilişkiye dair daha önce belirlenen bir hipotezin, teorinin ya da modelin sınanması söz konusudur ve yapı geçerliğinin incelenmesinde kullanılan temel yöntemlerden biridir (45-49). DFA'da ölçeğin faktör yapısının (modelin) geçerliliğini değerlendirmek için çok sayıda uyum indeksi kullanılmaktadır. Bunlar içinde en sık kullanılan beşi; Iyilik Uyum İndeksi (Goodness of Fit Index, GFI), Düzeltilmiş Iyilik Uyum Indeksi (Adjusted Goodness of Fit Index, AGFI), Ortalama Hataların Karekökü (Root Mean Square Residuals, RMR veya RMS) ve Yaklaşık Hataların Ortalama Karekökü'dür (Root Mean Square Error of Approximation, RMSEA). Alan yazında GFI, AGFI, NFI, NNFI ve CFI değerlerinin 0,90 civarında ve üzerinde, RMSEA ve RMR değerlerinin ise 0,10 'dan düşük çıkması modelin gerçek verilerle uyumu için birer ölçüt olarak kabul edilmektedir $(45,50,51,52,53)$. 2/sd oranının da 05 arasında olması beklenir $(48,50,51,53,54,55)$.

Ölçek puanları ile benzer özellikleri ölçen ölçeklerden elde edilen puanlar arasındaki ilişkiler için Pearson korelasyon katsayısı hesaplanmışıtı. Ölçek puanlarının iç tutarlıığı için Cronbach alfa ve Spearman-Brown iki yarı güvenirliği hesaplanmıştır. Aynı çocuklardan iki farklı zamanda elde edilen puanların test-tekrar test güvenilirliği için iki puan seti arasındaki ilişkiler yine Pearson korelasyon katsayısı kullanılarak incelenmiştir. İki farklı gruptan elde edilen puanlar arasındaki farklııkların anlamlılığını test etmek için ise t-testi kullanılmıştır.

\section{Bulgular}

\section{A.Geçerlik Çalışmaları Yapı Geçerliği}

CADÖ-YK'nın yapı geçerliği DFA; alt ölçekler arası korelasyonlar; Conners Ana-Baba Dereceleme Ölçeği-Yenilenmiş Uzun-CÖDÖ-YU, Conners Ana-Baba Öğretmen Dereceleme Ölçeği48 (CÖDÖ-48) ve Yenilenmiş Problem Davranış Kontrol Listesi (YPDKL) arasındaki ilişkiler ve madde analizi yoluyla incelenmiştir.

CADÖ-YK'nın 6-17 yaş arası Türk çocuklarının anababalarından elde edilen veriler üzerinden yapılan DFA ile elde edilen uyum istatistikleri şunlardır: $\quad \mathrm{x} 2 / \mathrm{sd}=1211: 130=9,32 ; \quad \mathrm{RMSEA}=0,058$, $\mathrm{RMR}=0,027, \mathrm{GFI}=0,95, \mathrm{AGFl}=0,93, \mathrm{CFI}=0,97, \mathrm{NFI}=0,97, \mathrm{NNFI}=0,97^{\prime} \mathrm{d}$ Ir. Maddelerin faktör standardize katsayıları (yük değerleri) ise 0.33 ile 0.68 arasında değişmekte olup, tümü 0,001 düzeyinde anlamlıdır.

DEHB Için DFA ile elde edilen uyum istatistikleri ise $\mathrm{x}^{2} / \mathrm{sd}=431,51: 53=8,14 ; \quad \mathrm{RMSEA}=0,051 ， \mathrm{RMR}=0,021 ， \quad \mathrm{GFI}=0,97$ ， AGFI $=0,96, C F I=0,96, N F I=0,95, N N F I=0,95$ 'dır. Maddelerin faktör standardize katsayıları (yük değerleri) 0,33 ile 0,60 arasındadır ve tümü 0,01 düzeyinde anlamlıdır.

Bir ölçeğin yapı geçerliği, o ölçeği oluşturan alt ölçekler arası korelasyonların hesaplanması yoluyla da incelenmektedir. Bu amaçla, CABDÖ-YK"nın alt ölçekler arasındaki korelasyonlar hesaplanmış ve sonuçlar Tablo 2'de verilmiştir.

Tablo 2'de görüldüğü gibi tüm alt ölçekler arası korelasyonlar 0.49-0.60 arasında değişmektedir ve tümü de anlamlıdır $(p<0,001)$. 
Alt ölçek puanları arasında en yüksek korelasyonlar Karşı Gelme ile Hiperaktivite $(0,60)$ ve Hiperaktivite ile Bilişsel ProblemlerDikkatsizlik arasındadır $(0,57)$. CÖDÖ-YK'nın alt ölçeklerinin DEHB Indeksi arasındaki korelasyonlar ise daha yüksektir (0,63-0,82).

Tablo 2. CADÖ-Y:K alt ölçekleri arasındaki korelasyonlar ( $\mathrm{n}=2736)$

\begin{tabular}{lccc}
\hline Alt Ölçekler & BP/D & H & DEHS \\
\hline KG & $0,49^{* *}$ & $0,60^{* *}$ & $0,63^{* *}$ \\
BP/D & & $0,57^{* *}$ & $0,82^{* *}$ \\
H & & $0,65^{* *}$ \\
\hline ** P<0.01 & & \\
Conners Ana-Baba Dereceleme Ölçeği-Yenilenmiş KIsa (CADÖ-YK): KG:karşı Gelme, \\
BP/D: Bilişsel Problemler/Dikkatsizlik, H: Hiperaktivite, DEHB: DEHB Indeksi
\end{tabular}

Tablo 3. CADÖ-YK ile CADÖ-YU alt ölçekleri arasındaki korelasyonlar (N=22)

\begin{tabular}{|c|c|c|c|c|}
\hline \multirow{2}{*}{$\begin{array}{l}\text { Ölçek } \\
\text { CADÖ-YU }\end{array}$} & \multicolumn{4}{|c|}{ CADÖ-YK } \\
\hline & $K G$ & BP-D & H & DEHB \\
\hline$K G$ & $0,70^{* *}$ & & & \\
\hline BP-D & & $0,49^{*}$ & & \\
\hline $\mathrm{H}$ & & & $0,81^{* *}$ & \\
\hline DEHB & & & & $0,53^{*}$ \\
\hline \multicolumn{5}{|c|}{$P<0,05$, ** $P<0,01$} \\
\hline \multicolumn{5}{|c|}{$\begin{array}{l}\text { Conners Ana-Baba Dereceleme Ölç eği-Yenilenmiş Kısa (CADÖ-YK): KG:karşı Gelme, } \\
\text { BP-D: Bilişsel Problemler-Dikkatsizlik, H: Hiperaktivite, DEHB: DEHB Indeksi. Conners } \\
\text { Ana-Baba Dereceleme Ölçeği-Yenilenmiş Uzun (CADÖ-YU): KG:karşı Gelme, } \\
\text { BP-D: Bilişsel Problemler-Dikkatsizlik, H: Hiperaktivite, DEHB:DEHB Indeksi. }\end{array}$} \\
\hline
\end{tabular}

CADÖ-YK'nın Conners Ahababa Dereceleme Ölçeği-Yenilenmiş Uzun-CADÖ-YU ile ilişkileri Tablo 3'de verilmiştir.

Tablo 3'de de izlendiği gibi Conners anababa ölçeklerinin kısa ve uzun formlarının aynı adlı alt ölçekleri arasındaki korelasyonlar 0,49 ile 0,81 arasındadır.

Yapı geçerliği için ayrıca CADÖ-YK'nın Conners Ana-Baba Dereceleme Ölçeği-48 (CADÖ-48) ve Yenilenmiş Problem Davranış Kontrol Listesi (YPDKL) arasındaki ilişkiler incelenmiş ve bulgular Tablo 4'de verilmiştir.

Tablo 4'e göre CADÖ-YK ile CADÖ-48 arasındaki korelasyonlar 0,23 ile 0,74 arasındadır. En yüksek korelasyonlar Karşı Gelme ile Davranım Sorunları $(0,74)$, Dikkat Eksikliği Hiperaktivite Bozukluğu Indeksi ile Öğrenme Sorunları $(0,70)$, Dikkat Eksikliği Hiperaktivite Bozukluğu İndeksi ile Davranım Sorunları $(0,68)$ arasındadır.

CADÖ-YK ve YPDKL arasındaki ilişkiye bakııdığında bu ilişkilerin 0,07-0,52 arasında değiştiği; en yüksek ilişkilerin sırasıyla Dikkat Eksikliği Hiperaktivite Bozukluğu Indeksi ile Dikkat Problemleri-Toyluk $(0,52)$, Karşı Gelme ile Davranım Bozukluğu $(0,49)$, Hiperaktivite ile Motor Gerilim $(0,49)$ arasında olduğu gözlenmektedir.

Madde analizi. CADÖ-YK için iki türlü madde analizi yapılmıştır. Bunlardan ilkinde her bir maddenin kendi faktörü için düzeltilmiş madde-toplam korelasyonları da hesaplanmıştır. Madde ayırt edicilik düzeyi olarak da yorumlanan düzeltilmiş madde-toplam korelasyonları Karşı Gelme için 0,46-0,69, Hiperaktivite için 0,41-0,57, Bilişsel Problemler-Dikkatsizlik için 0,52-0,69, DEHB İndeksi için 0,32-0,65 arasında değişmektedir. Íkinci tür analizde ise CADÖYK'dan aldıkları puanlar itibariyle alt \%27'lik ve üst \%27'lik gruplarda yer alan katılımcıların puan ortalamaları t tesiti ile kıyaslanmış ve sonuçlar Tablo $5^{\prime}$ de verilmiştir.

Tablo 5'e göre üst \%27'lik grupta yer alanların puan ortalamaları Karşi Gelme alt ölçeğinde [t=83,96; $p<0,00]$, Bilissel Problemler-

Tablo 4. CADÖ-YK ile CADÖ-48 ve YPDKL arasındaki korelasyonlar

\begin{tabular}{|c|c|c|c|c|c|c|c|c|c|c|c|}
\hline \multirow[t]{2}{*}{ CADÖ-YK } & \multicolumn{5}{|c|}{ CADÖ-48 (n=168) } & \multicolumn{6}{|c|}{ YPDKL $(n=585)$} \\
\hline & DS & AH & ÖS & K & $\mathbf{P}$ & DB & TS & DP-T & K-İK & PD & MG \\
\hline KG & $0,74^{* *}$ & $0,46^{* *}$ & $0,44^{* *}$ & $0,39 * *$ & $0,38^{* *}$ & $0,49 * *$ & $0,17^{* *}$ & $0,38^{* *}$ & $0,33^{* *}$ & $0,28^{*}$ & $0,32^{* *}$ \\
\hline BP-D & $0,59 * *$ & $0,34^{* *}$ & $0,57^{* *}$ & $0,33^{* *}$ & $0,29 * *$ & $0,20^{* *}$ & 0,07 & $0,40^{* *}$ & $0,27^{* *}$ & $0,25^{* *}$ & $0,28 * *$ \\
\hline $\mathrm{H}$ & $0,59 * *$ & $0,59^{* *}$ & $0,44^{* *}$ & $0,23^{* *}$ & $0,32^{* *}$ & $0,38^{* *}$ & $0,14^{* *}$ & $0,39 * *$ & $0,28^{* *}$ & $0,37^{* *}$ & $0,49^{* *}$ \\
\hline DEHB & $0,68^{* *}$ & $0,48^{* *}$ & $0,70^{* *}$ & $0,46^{* *}$ & $0,42^{* *}$ & $0,30 * *$ & $0,12^{*}$ & $0,52^{* *}$ & $0,42^{* *}$ & $0,37^{* *}$ & $0,34^{* *}$ \\
\hline
\end{tabular}

${ }^{*} p<, 05 \quad{ }^{* *} p<, 001$

Conners Anababa Dereceleme Ölçeği-Yenilenmiş Kısa (CADÖ-YK): KG:karşı Gelme, BP-D: Bilişsel Problemler-Dikkatsizlik, H: Hiperaktivite, DEHB:DEHB Indeksi. Conners Anababa Dereceleme Ölçeği-48 (CABDÖ-48): DS: Davranım Sorunları; AH: Ataklık Hiperaktivite; ÖS: Öğrenme Sorunları; K: Kaygl; $p=$ Psikosomatik. Yenilenmiş Problem Davranış Kontrol Listesi (YPDKL): DB: Davranım Bozukluğu; TS: Toplumsallaşmış Saldırganlık; DP-T: Dikkat Problemleri-Toyluk; KIK: Kaygı/lçe Kapanma; PD: Psikotik Davranış; MG: Motor Gerilim

Tablo 5. Alt ve üst \%27'lik grupların puan ortalamalarına ilişkin t testi sonuçları

\begin{tabular}{|c|c|c|c|c|c|c|c|}
\hline \multirow[t]{2}{*}{ CADÖ-YK } & \multicolumn{3}{|c|}{ Alt \%27 } & \multicolumn{3}{|c|}{ Üst \%27 } & \multirow[b]{2}{*}{$T$} \\
\hline & $\mathrm{n}$ & $x$ & ss & n & $x$ & ss & \\
\hline KG & 675 & 0,47 & 0,50 & 875 & 9,03 & 2,96 & $83,96^{* *}$ \\
\hline BP-D & 786 & 0,00 & 0,00 & 860 & 6,91 & 2,95 & $68,57^{* *}$ \\
\hline H & 772 & 0,00 & 0,00 & 824 & 6,48 & 2,73 & $68,21^{* *}$ \\
\hline DEHB & 799 & 1,41 & 1,19 & 868 & 15,14 & 4,91 & $79,92^{* *}$ \\
\hline
\end{tabular}

${ }^{* *} \mathrm{p}<0,001$

Conners Anababa Dereceleme Ölçeği-Yenilenmiş Kısa (CADÖ-YK): KG:karşı Gelme, BP-D: Bilişsel Problemler-Dikkatsizlik, H: Hiperaktivite, DEHB: DEHB Indeksi 
Tablo 6. CADÖ-YK ile CÖDÖ-YK ve C-WEÖÖ-YK ölçekleri arasındaki korelasyonlar

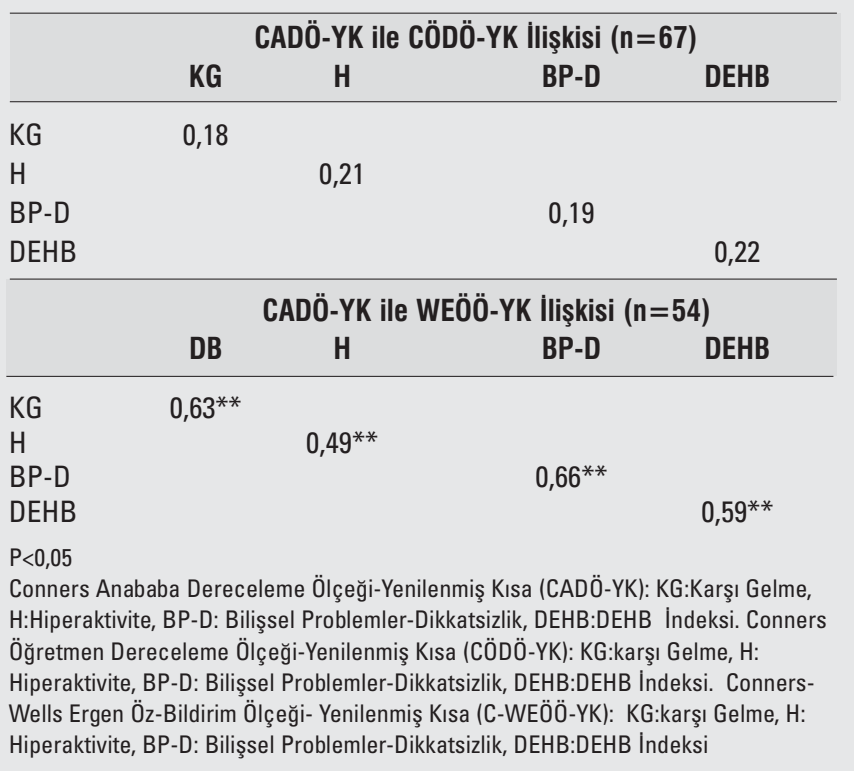

Dikkatsizlik alt ölçeğinde $[t=68,57 ; \quad p<0,00]$, Hiperaktivite alt ölçeğinde $[t=68,21 ; p<0,00]$, DEHB İndeksi'nde $[t=79,92 ; p<0,00]$ alt $\% 27$ 'lik grubunkilerden daha yüksektir.

CADÖ-YK'nın geçerliği CÖDÖ-YK ve C-WEÖÖ-YK ile ilişkileri ile incelenmiş ve bulgular Tablo 6 'da verilmiştir.

Tablo 6'daki bulgular incelendiğinde CADÖ-YK ile CÖDÖ-YK alt ölçekler arası korelasyonların hiçbiri anlamlı bulunmamışıı. Buna karşın, CADÖ-YK ile C-WEÖÖ-YK tüm alt ölçeklerindeki korelasyonlar orta düzeyde ve anlamlıdır $(0,49-0,66, p<0,001)$.

\section{B. Güvenirlik Çalışmaları}

CADÖ-YK'nın güvenirliğini belirlemek amacıyla aracın iç tutarllığı Cronbach Alfa ve Spearman-Brown iki yarı güvenirlik katsayısıyla incelenmiştir. Ayrıca, aracın ne derece tutarlı ölçüm yaptığını belirlemek için test-yeniden test güvenirliği de hesaplanmıştır. CÖDÖ-YK alt ölçeklerinin Cronbach alfa, SpearmanBrown iki yarı ve test-yeniden test güvenirlik değerleri Tablo 7'de verilmiştir.

CABDÖ-YK puanlarından elde edilen Cronbach alfa katsayıları 0,73-0,86, Spearman-Brown iki yarı güvenirlik katsayıları 0,72 ile 0,85 arasındadır. Test-yeniden test güvenirliği için CADÖ-YK, 80 çocuğun anababalarına sekiz hafta ara ile ikişer kez verilmiştir. İki puan seti

Tablo 7. CADÖ-YK alt ölçek puanlarının cronbach alfa iç tutarlılık ve test-tekrar test güvenilirlik katsayıları

\begin{tabular}{|c|c|c|c|c|}
\hline Güvenirlik & KG & $B P / D$ & H & DEHB \\
\hline Alfa $(n=2736)$ & 0,83 & 0,83 & 0,73 & 0,86 \\
\hline Iki yarı (n=2736) & 0,85 & 0,80 & 0,72 & 0,84 \\
\hline Test-tekrar-test $(n=80)$ & $0,62^{* *}$ & $0,56^{* *}$ & $0.56^{* *}$ & $0,72^{* *}$ \\
\hline
\end{tabular}

Tablo 8. Yaş ve cinsiyete göre CADÖ-YK alt ölçeklerinden alınan puanların ortalamaları ve standart sapmaları

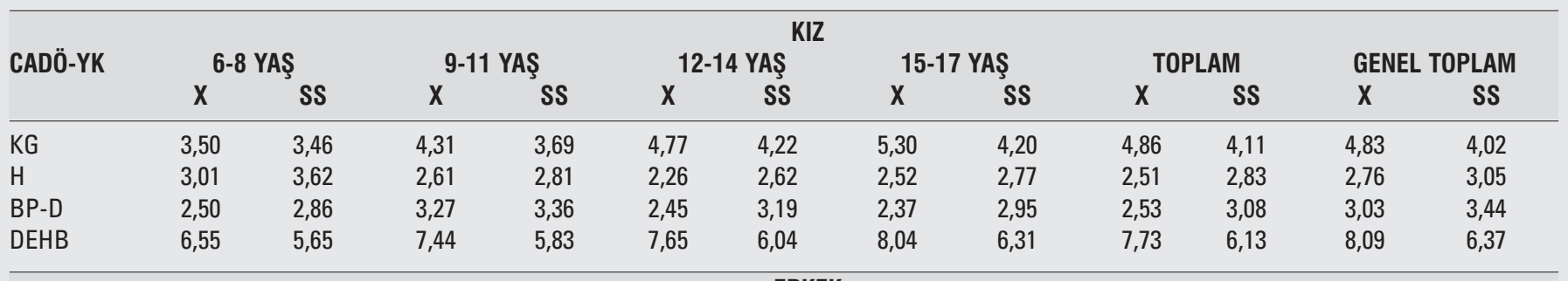

\begin{tabular}{|c|c|c|c|c|c|c|c|c|c|c|}
\hline \multirow{3}{*}{ CADÖ-YK } & \multicolumn{8}{|c|}{ ERKEK } & \multirow{2}{*}{\multicolumn{2}{|c|}{ TOPLAM }} \\
\hline & \multicolumn{2}{|c|}{ 6-8 YAŞ } & \multicolumn{2}{|c|}{ 9-11 YAŞ } & \multicolumn{2}{|c|}{ 12-14 YAŞ } & \multicolumn{2}{|c|}{ 15-17 YAŞ } & & \\
\hline & $x$ & SS & $x$ & SS & $X$ & SS & $x$ & SS & $x$ & SS \\
\hline KG & 4,40 & 3,60 & 5,03 & 3,97 & 4,82 & 4,06 & 4,72 & 3,77 & 4,78 & 3,89 \\
\hline $\mathrm{H}$ & 3,68 & 3,21 & 3,60 & 3,79 & 2,89 & 3,24 & 2,70 & 2,94 & 3,12 & 3,32 \\
\hline BP-D & 3,41 & 2,91 & 3,96 & 4,30 & 4,38 & 4,09 & 3,15 & 3,32 & 3,78 & 3,80 \\
\hline DEHB & 7,64 & 5,46 & 8,89 & 7,09 & 9,39 & 7,25 & 8,04 & 6,11 & 8,63 & 6,68 \\
\hline
\end{tabular}

\begin{tabular}{|c|c|c|c|c|c|c|c|c|}
\hline \multicolumn{9}{|c|}{ TOPLAM } \\
\hline & \multicolumn{2}{|c|}{ 6-8 YAŞ } & \multicolumn{2}{|c|}{ 9-11 YAS } & \multicolumn{2}{|c|}{ 12-14 YAS } & \multicolumn{2}{|c|}{ 15-17 YAS } \\
\hline & $x$ & SS & $x$ & SS & $x$ & SS & $x$ & SS \\
\hline KG & 3,97 & 3,55 & 4,67 & 3,84 & 4,79 & 4,15 & 5,13 & 4,09 \\
\hline $\mathrm{H}$ & 3,37 & 3,41 & 3,12 & 3,39 & 2,55 & 2,94 & 2,57 & 2,82 \\
\hline BP-D & 2,95 & 2,91 & 3,61 & 3,86 & 3,33 & 3,75 & 2,60 & 3,08 \\
\hline DEHB & 7,12 & 5,56 & 8,14 & 6,50 & 8,44 & 6,67 & 8,04 & 6,25 \\
\hline
\end{tabular}


arasında hesaplanan test-yeniden test güvenirlik katsayıları, 0,56$0,72(\mathrm{P}<0,001)$ arasında değişmektedir (Tablo 7).

Çocukların CADÖ-YK'nın ölçek puanlarının ortalama ve standart sapma değerleri yaş gruplarına ve cinsiyete göre Tablo 8'de verilmiştir.

\section{Tartışma}

Bu çalıșmada, CADÖ-YK'nın yapısının Türk çocuklarının anababalarından elde edilen veriler ile ne derece uyumlu olduğu incelenmiștir. CADÖ-YK'nın yapısal özellikleri çeșitli tekniklerle sınanmıştı. Bunlardan ilkinde, Türk örnekleminden elde edilen verilere uygulanan DFA sonuçları, CADÖ-YK'nın özgün yapısının korunduğunu ortaya koymuştur. Elde edilen uyum indeks değerleri hem CADÖ-YK $\left(\chi^{2} / \mathrm{sd}=1211: 130=9,32 ; \mathrm{RMSEA}=0,058, \mathrm{RMR}=0,027\right.$, $\mathrm{GFI}=0,95, \mathrm{AGFI}=0,93, \mathrm{CFI}=0,97, \mathrm{NFI}=0,97, \mathrm{NNFI}=0,97)$ hem de $\mathrm{DEHB}$ Indeksi $\left(\chi^{2} / \mathrm{sd}=431,51: 53=8,14 ; \mathrm{RMSEA}=0,051, \mathrm{RMR}=0,021, \mathrm{GFI}=0,97\right.$, AGFI $=0,96, C F I=0,96, N F I=0,95, N N F I=0,95)$ için kabul ölçütlerini karşılamaktadır. Alan yazında GFI, AGFI, NFI, NNFI ve CFI değerlerinin 0,90 ve üzerinde, RMSEA ve RMR değerlerinin ise 0,10 'un altında çıkması modelin gerçek verilerle uyumu için birer ölçüt olarak kabul edilmektedir $(45,49,50,51,52,53)$. Bu çalışma ile elde edilen GFI, AGFI, NFI, NNFI ve CFI değerlerinin 0,90'ın oldukça üzerinde, RMSEA ve RMR değerlerinin ise modelin uyumu açısından verilen sınır değerlerin oldukça altında olduğu görülmektedir. Buna göre, CADÖ-YK'nın üç faktörlü özgün yapısının Türk kültürü için çok iyi bir uyum gösterdiği söylenebilir. DEHB Indeksinden elde edilen uyum indeks değerleri de kabul sınırları içerisindedir. Uyum değerleri istendik koşulları karşıladığı için açımlayıcı faktör analizi yapılmamışıır.

Conners üç alt ölçeğin sadece bazı uyum indeks değerlerini açıklamıştır (GFI=0,94, $\mathrm{AGFI}=0,93, \quad \mathrm{RMS}=0,04) \quad$ (7). Türkiye çalışmasından elde edilen değerlerin, Conners'ınkilerle benzer olduğu gözlenmektedir. Alan yazında, CADÖ-YK'nın faktör yapısını inceleyen son derece sınırlı çalışmaya ulaşılabilmiştir. Bunlardan ilkinde Gau ve arkadaşları 6-16 yaşlarındaki 2584 çocuğun anababalarına CADÖ-YK'yı uygulayarak elde ettikleri verileri açımlayıcı faktör analizi ile incelemişlerdir (27). Bulgular, CADÖYK'nın Çinli çocuklar için bir madde dışında benzer faktör yapılarına sahip olduğunu, faktörlerdeki maddelerin yük değerlerinin Karşı Gelme için 0,48-0,67, Hiperaktivite için 0,45-0,67, dikkatsizlik için 0,56-0,67 arasında olduğunu ortaya koymuştur. CADÖ-YK'nın İspanyolca sürümüyle ilgili çalışmada doğrulayıcı faktör analizi, Ispanyolca sürümünün özgün ölçeğin yapısına çok benzediğini (GFI: 0,98, CFI: 0,98, RMSEA: 0,05) ortaya koymuştur (Akt., 29). Bu çalışmanın el kitabına ulaşılamadığı için kapsamlı karşış̧̧ııma yapılamamışır. İsmail ve arkadaşları CADÖ-YK'yı Malezya diline çevirmişler ancak geçerlik ve güvenirlik çalışmasını yapmadan kullanmışlardır (30). Benzer durum, Avusturalya (20), İsviçre (15) ve Almanya çalışmaları $(22,26)$ için de geçerlidir. Ingiltere'deki çalışma ise farklı bir grup üzerinde yürütülmüştür. Deb ve arkadașları (13) Ingiltere'de zihin engelli çocukların anababalarından elde edilen verilere açımlayıcı faktör analizi uygulamışlardır. Analiz sonucunda maddeler üç faktörde toplanmıştır. Dikkatsizlik, Hiperaktivite ve Davranım Problemleri. Özgün ölçekte Karşı Gelme, Bilişsel Problemler-Dikkatsizlik ve Hiperaktivite alt ölçeklerinde yer alan maddeler, yukarıda aynı ve/veya benzer şekilde kavramsallaştırımış alt ölçeklerde toplanmışlar, DEHB Indeksindeki maddeler de bu üç alt ölçeğe dağılmışlardır.

Farklılıkları olan çocukların anababalarıyla yapılmış iki çalışma daha vardır. Bunlardan biri psikiyatrik tanıları olan ve ayaktan tedavi alan 5-16 yaşlarındaki çocukların anababalarıyla yürütülmüştür. Kumar \& Steer (24) CADÖ-YK'nın yapısını önce doğrulayıcı daha sonra da açımlayıcı faktör analizi ile incelemiş ve iki faktöre ulaşmıșlardır: DEHB Toplam Semptomlar ve Karșı Gelme. Diğer çalışma ise 6-18 yaşındaki kanser hastası çocukların anababalarıyla yapılmıştır (56). Doğrulayıcı faktör analizi sonuçları, bu grupta özgün yapının korunduğunu ancak uyum indeks değerlerinin kabul edilen ölçütleri yeterince karşılamadığını (RMS:0.09, GFI: 0,71, AGFI: 0,61, RMSEA: 0,05, NFI: 0,84, NNFI: 0,83, CFI: 0.86) gösterince açımlayıcı faktör analizi uygulayan araştırmacılar varyansın \%62,9'unu açıklayan üç faktörlü bir yapıya ulaşmışlardır. Helton ve arkadaşları, bu üç faktörün, tek bir madde dışında Conners'ın Hiperaktivite, Bilişsel Problemler-Dikkatsizlik ve Karşı Gelme faktörleriyle uyuştuğunu bildirmişlerdir (7).

Uyum indeks değerleriyle ilgili bir diğer ölçüt $\mathrm{x}^{2} /$ sd oranıdır. Türkiye çalışmasında $x^{2} /$ sd için elde edilen değerler, kabul edilir uyum değerinin üzerindedir $\left(x^{2} / \mathrm{sd}=1211: 130=9.32 ; \quad x^{2} / \mathrm{sd}=431,51: 53=8,14\right)$. Alan yazında, $x$ 2/sd oranının 2 veya altında olması modelin iyi bir model olduğunu, 2-5 arasında olması ise modelin kabul edilebilir bir uyum iyiliğine sahip olduğunu göstermektedir $(48,50,51,55)$. Diğer taraftan, $x^{2}$ değeri, örneklem büyüklüğüne duyarlıdır ve örneklem büyüklüğü 200 ya da üzerinde olduğunda $x^{2}$ değeri de büyümektedir $(49,54,57)$. Türkiye çalışmasında veri toplanan anababa sayısı dikkate alındığında ( $\mathrm{n}=2736)$, elde edilen yüksek oranı örneklem büyüklüğüne bağlayabiliriz. Floyd \& Wideman (Akt., 57), bu sorunun üstesinden gelebilmenin bir yolu olarak büyük tek bir örneklem üzerinde modelin test edilmesi yerine örneklemi alt birimlere bölerek analiz yapmayı önermektedirler. Yazarlar, bu şekilde yapılan analizin ayrıca modelin uyumu için ilave bir kanıt da olacağını bildirmektedirler. İleri çalışmalarda, analizlerin bu öneri doğrultusunda yenilenmesinde yarar vardır. Conners, bu orana ilişkin bilgi vermemiştir (7).

Türkiye çalışmasında faktörlerdeki madde yük değerleri kısa form için 0,33-0,60, DEHB İndeksi için 0,33 ile 0,68 arasındadır ve tümü anlamlıdır $(p<0,01)$. Maddelerin faktör yük değerlerinin 0,40 ve üzerinde olması durumunda, bu maddelerin "çok iyi", 0,70 ve üzerinde olması durumunda ise bu maddelerin "mükemmel" olarak değerlendirileceğini ifade etmektedir (49). Bu durumda, maddelerin ilgili faktörler ile oldukça güçlü ilişkileri olduğunu söyleyebiliriz. Conners'ın (7), Gau ve arkadaşlarının (27), Deb ve arkadaşlarının (13) çalışmalarında, üç alt ölçek maddelerinin faktör yük değerleri daha yüksektir (sırasıyla 0,44-0,74; 0,45-0,67; 0,41-0,84).

CADÖ-YK'nın yapı geçerliğine ilişkin bir diğer kanıt alt ölçekler arası korelasyonların incelenmesiyle elde edilmiştir. Alt ölçekler arası korelasyonların orta düzeyde ve tümünün anlamlı olduğu $(0,49-0,60)$, DEHB İndeksi de analize dahil edilince bu korelasyonların yükseldiği $(0,63-0,82)$ bulunmuştur. Faktörler arası korelasyonların orta ile yüksek arasında değişmesi, verilerin bir noktada birleştiğinin bir göstergesidir (58). Bu bulgu, CADÖ-YK'nın alt ölçeklerinin ve DEHB İndeksinin birbirlerine bağımlı olduğunun da bir göstergesi olarak değerlendirilebilir (59). Alan yazın da bu 
çalışmada olduğu gibi, bu problem alanlarının birlikte bulunma sıklıklarının yüksek olduğuna ilişkin pek çok bulgu sunmaktadır $(1,2,60,61,62,63)$. Conners'ın çalışmasında, üç alt ölçeğin ve DEHB Indeksi'nin arasındaki korelasyonlar erkeklerde 0,53-0,71, kızlarda $0,48-0,87$ arasındadır $(p<0,05)$ (7). Bu değerleri Helton ve arkadaşları (56) 0,52-0,68, Schneider ve arkadaşları ise 0,36-0,74 olarak bildirmişlerdir (29). Görüldüğü gibi dört çalışma içinde en düşük korelasyonlar Türkiye çalışması için elde edilmiştir.

CADÖ-YK'nın geçerliği, benzer kavramsal yapıları ölçen diğer ölçme araçları kullanılarak da incelenmiştir. Bu amaçla, CADÖ-YK ile CADÖ-YU, CADÖ-48, CÖDÖ-YK, C-WEÖÖ-YK ve YPDKL arasındaki ilişkiler test edilmiştir.

CADÖ'nin kısa ve uzun formlarının aynı adı taşıyan alt ölçekleri arasındaki korelasyonlar ortadan yükseğe doğru değişmektedir $(0,49-0,81)$. Bu durumda, kısa ve uzun formların yeri geldiğinde birbirlerinin yerine kullanılabileceğini söyleyebiliriz. Conners'da uzun formların kapsamlı değerlendirmeye gereksinim olduğunda, kısa formların ise zaman sınırlı olduğunda ve sık kullanım söz konusu olduğunda kullanılmalarını önermektedir (7). Conners kısa ve uzun formların kıyaslamasını yapmadığı için iki çalışmanın bulguları bu analiz açısından değerlendirilememiştir (7). CADÖ-YK ile CADÖ-48 arasındaki korelasyonlar ise biraz daha düşük gözükmektedir (0,23-0,74).

CDÖ-YK'nın anababa, öğretmen ve ergen formları arasındaki korelasyonlara ilişkin bulguların alan yazın ile tutarlı olduğunu söyleyebiliriz. Anababa-ergen tutarlılığı orta düzeyde ve tüm alt ölçeklerde anlamlıyken $(0,49-0,66)$, anababa-öğretmen tutarlıığı çok düşüktür ve hiçbir alt ölçek için anlamlı değildir $(0,18-0,22)$. CADÖ-YK'nın CÖDÖ-YK ile ilişkilerini inceleyen araştırmacıların bazıları bu ilişkiyi düşük $(7,13,27,29)$, bazıları da orta düzeyde bulmuşlardır (7,14-16,56). Conners'ın (7) ve Parker ve arkadaşlarının (25) CADÖ-YK ile C-WEÖÖ-YK arasındaki korelasyonları Türkiye çalışmasından daha düşük bulunmuştur (sırasıyla erkeklerde 0,16-0,53, kızlarda 0,01-0,42; 0,39-0,45). Alan yazında pek çok çalışma da anababa-öğretmen tutarlılığının, anababa-ergen tutarlılığından daha düşük olduğu bildirmiştir $(64,65,66)$. Bu bulgu, anababaların öğretmenlerden daha çok çocuklarıyla benzer görüşleri paylaştıklarını ifade etmektedir. Bu bulgu aynı zamanda, öğretmen, anababa ve ergenin problem davranışları farklı algılayıp değerlendirdiklerini de ortaya koymaktadır. Bu durumu, farklı bilgi kaynaklarının görüşlerini geçersiz olarak görmek yerine farklı bilgi kaynaklarının problem davranışları belirleme sürecine farklı şekilde katkıda bulundukları şeklinde değerlendirmek daha doğru olacaktır (67). Bir diğer deyişle, bir bilgi kaynağının yerini, bir diğeri alamamaktadır (64).

Anababa, öğretmen ve ergen formları arasındaki korelasyonların düşük olması ise farklı bilgi kaynakları arasındaki ilişkilerin düşükten orta düzeye doğru değiştiğini gösteren pek çok alan yazın bulgusu ile paralellik göstermektedir $(7,13,16,27,29,56,64,66,68,69,70,71,72,73,74)$.

CADÖ-YK ile benzer yapıları ölçen CADÖ-48 arasındaki korelasyonların ise $(0,23-0,74)$ CADÖ-YK'nın YPDKL ile arasındaki korelasyonlardan daha yüksek olduğu gözlenmektedir. Conners'ın yenilenmiş ve eski formlarındaki pek çok maddenin aynı olduğu düşünüldüğünde bu sonuç şaşırtıcı değildir. Conners (7) yenilenmiş kısa formların eski formlarla ilişkilerini incelememiştir.

CADÖ-YK'nın yapı geçerliği iki tür madde analiziyle de analiz edilmiştir. Bunlardan ilki olan madde-toplam test korelasyonları incelendiğinde, CADÖ-YK'nın madde ayırtedicilik indeks değerlerinin (maddelerin toplam puanı yordama güçlerinin) oldukça yüksek olduğu gözlenmektedir (Karşı Gelme için 0,46-0,69, Hiperaktivite için 0,41-0,57, Bilişsel Problemler-Dikkatsizlik için 0.520.69 , DEHB İndeksi için 0,32-0,65). Madde ayırtedicilik indeks değerlerinin 0.40 ve üzerinde olan maddelerin "çok iyi" ayırt edici maddeler olarak değerlendirildiği düşünüldüğünde, CADÖ-YK'nın alt ölçek maddelerinin ayırt ediciliğinin-geçerliğinin yüksek olduğunu söyleyebiliriz $(58,59,75,76)$.

İkinci madde analizinde ise alt ölçeklerinin ölçmeyi hedeflediği özelliğe yüksek düzeyde sahip olanlar ile düşük düzeyde sahip olanları ne derece ayırt ettiğini belirlenmiştir. Toplam puan üzerinden alt \%27 ile üst \%27'lik grupların kıyaslanması sonucunda, tüm alt ölçeklerde ve DEHB İndeksinde farklar üst \%27'lik grubun aleyhine anlamlı bulunmuştur. Bu durumda, ölçekteki maddelerin alt ve üst grupları iyi ayırt ettiğini sonucuna ulaşılmıştır $(58,76)$. Ancak, ileri analizlerde CADÖ-YK'nın ayırt edici geçerliğinin öncelikle DEHB olmak üzere farklı tanısı olan ve olmayan gruplarda kıyaslanması gerekmektedir. Diğer çalışmalarda $(7,13,16,24,27,29)$, DEHB olan ergenlerin, CADÖ-YK'nın tüm alt ölçeklerinde tanısı olmayan ergenlerden daha yüksek puan aldıklarını bildirmiştir.

CADÖ-YK'nın Türkçe sürümünde Cronbach alfa ve iki yarı güvenirlik değerleri (sırasıyla 0,73-0,86; 0,72-0,85) ve test-tekrar test güvenirliği $(0,56-0,72)$, Schneider ve arkadaşlarının (29) alfa değerleriyle daha çok benzeşiklik gösterirken (0,73-0,78), Conners'ın (7) (Cronbach alfa: 0,88-0,95, test-yeniden test: 0,72$0,92)$, Gau ve arkadaşlarının (27) $(0,84-0,91)$ ve Gau'nun (14) $(0,85-$ $0,95)$ güvenirlik değerlerinden bir miktar daha düşüktür. İç tutarlıığın yüksek olması, söz konusu ölçeğin hem maddelerinin ölçmenin bütünüyle tutarlı olduğunun hem de yapı geçerliğinin bir göstergesidir (59). Test-tekrar test korelasyonlarının yüksek oluşu ise ölçek puanlarının kararlı olduğunu, ölçülen özellik açısından zaman içerisinde fazla bir değişme olmadığını ve tutarlı bir ölçüm yaptığını ortaya koymaktadır $(59,75)$. Güvenirlik değerleri topluca değerlendirildiğinde CADÖ-YK'nın araştırmalarda güvenle kullanılabilecek sınırlarda olduğu söylenebilir.

Hemen her araştırmada olduğu gibi bu araştırmanın da bazı sınırlılıkları bulunmaktadır. Bunlardan ilki, verilerin sadece ulaşabilir örneklemler yoluyla toplanmış olmasıdır. Sonraki çalışmalarda, Türkiye'nin yedi bölgesini temsil edecek şekilde aşamalı örnekleme yöntemiyle illerin ve illerdeki okulların seçilmesi uygun olacaktır. İkinci sınırlılık, verilerin 6-17 yaşındaki çocukların anababalarından toplanmış olmasıdır. Özgün CADÖYK formu, 3-17 yaşındaki çocukların anababalarından elde edilen yanıtlara dayalıdır. Bu nedenle, Türkiye örneklemi 3-5 yaş grubunu da içerecek şekilde düzenlenmeli ve ölçeğin psikometrik özelliklerinin yeniden incelenmelidir .

Bu sınırlııklarına rağmen bu çalışmadan elde edilen bulgulara topluca bakıldığında, CADÖ-YK'nın özgün yapısının, çocuk ve gençlerdeki problem davranışları değerlendirmek açısından kullanılabilir psikometrik özelliklere sahip olduğu söylenebilir. 


\section{Kaynaklar}

1. Ercan ES, Aydın C. Çocuk ve Adolesanda Ruhsal Bozukluklar. Dikkat Eksikliği Hiperaktivite Bozukluğu. Izmir; 1999.

2. Öner Ö, Soykan-Aysev A. Dikkat Eksikliği Hiperaktivite Bozukluğu. AA Soykan ve YI Taner (eds), Çocuk ve Ergen Ruh Sağlığı ve Hastalıkları. Ankara: Janssen-Cilag; 2007. s. 397-420.

3. Öncü B, Şenol S. Dikkat Eksikliği Hiperaktivite Bozukluğunun Etiyolojisi: Bütüncül Yaklaşım. Klinik Psikiyatri 2002; 5:111-119.

4. Şenol S, Şener Ş. Dikkat eksikliği/hiperaktivite bozukluğu. C. Güleç ve E. Köroğlu (Eds.). Psikiyatri temel kitabı. Ankara : Hekimler Yayın Birliği; 1998. s. $1119-1130$.

5. DSM-IV-TR. Tanı ölçütleri. Başvuru el kitabı. (Çev. E. Koroğlu). Ankara: Hekimler Yayın Birliği (Orijinal eserin yayın tarihi 2000); 2001.

6. Conners CK. Manual for Conners' Rating Scales. WPS, Toronto; 1990.

7. Conners CK. Conners' Rating Scales-Revised. Instruments for use with children and adolescents. Toronto: MHS; 1997.

8. Conners CK, Wells KC, Parker JD, Sitarenios G, Diamond JM, Powell JW. A new self-report scale for assessment of adolescent psychopathology: Factor structure, reliability, validity and diagnostic sensitivity. J Abnorm Child Psychol 1997; 25:487-497.

9. Conners CK, Sitarenios G, Parker JD, Epstein JN. The Revised Conners' Parent Rating Scale (CPRS-R): Factor structure, reliability, and criterion validity. J Abnorm Child Psychol 1998; 26:257-268.

10. Conners CK, Sitarenios G, Parker JD, Epstein JN. Revision and restandardization of the Conners Teacher Rating Scale (CTRS-R): Factor structure, reliability and criterion validity. J Abnorm Child Psychol 1998; 26:279-291.

11. Fantuzzo J, Grim S, Mordell M, McDermott P, Miller L, Coolahan K. A multivariate analysis of the revised Conners' teacher rating scale with lowincome, urban preschool children. J Abnorm Child Psychol 2001; 29:141-152.

12. Molina BSG, Smith BH, Pelham WE. Factor structure and criterion validity of secondary school teacher ratings of ADHD and ODD. J Abnorm Child Psychol 2001; 29:71-82.

13. Deb S, Dhaliwal AJ, Roy M. The usefulness of Conners' Rating ScalesRevised in screening fo attention deficit hyperactivity disorder in children with intellectual disabilities and borderline intelligence. J Intellect Disabil Res 2008; 52:950-965.

14. Shur-Fen Gau S. Prevalence of sleep problems and their association with inattention/hyperactivity among children aged 6-15 in Taiwan. J Sleep Res 2006; 15:403-414.

15. Pierrehumbert B, Bader M, Thévoz S, Kinal A, Halfon O. Hyperactivity and attention problems in a Swiss sample of school-aged children. J Atten Disord 2006; 10:65-76

16. Sullivan JR, Riccio CA. Diagnostic group differences in parent and teacher ratings of the BRIEF and Conners' scales. J Atten Disord 2007; 11:398-406.

17. Biederman J, Heiligenstein $\mathrm{JH}$, Faries DE, Galil N, Dittmann R, Emslie GJ, Kratochvil CJ, Laws HF, Schuh KJ; Atomoxetine ADHD Study Group. Efficacy of atomoxetine versus placebo in school-age girls with attentiondeficit/hyperactivity disorder. Pediatrics 2002; 110:75-81.

18. Escobar R, Soutullo C, San Sebastián J, Fernández E, Julián I, Lahortiga F Atomexetine safety and efficacy in children with attention deficit/hyperactivity disorder (ADHD): Initial phase of 10-week treatment in a relapse prevention study in a Spanish sample. Actas Esp Psiquiatr 2005; 33:26-32.

19. Handen BL, Janosky J, Mcauliffe S. Long-term follow-up of children with mental retardation/borderline intellectual functioning and ADHD. J Abnorm Child Psychol 1997; 25:282-295.

20. Nikles CJ, Mitchell GK, Del Mar CB, McNairn N, Clavarino A. Long-term changes in management following n-of-1 trials of stimulants in attentiondeficit/hyperactivity disorder. Eur J Clin Pharmacol 2007; 69:985-989.

21. Reitman D, Hupp SD, O'Callaghan PM, Gulley V, Northup J. The influence of a token economyand methylphenidate on attentive and disruptive behaviors during sports with ADHD-diagnosed children. Behav Modif 2001; 25:305-323

22. Strehl U, Leins U, Goth G, Klinger C, Hinterberger T, Birbaumer N. SelfRegulation of slow cortical potentials: A new treatment for children with Attention-Deficit/Hyperactivity Disorder. Pediatrics 2010; 118:1530-1540.

23. Wei JL, Mayo MS, Smith HJ, Reese M, Weatherly RA. Improved behavior and sleep after adenotonsillectomy in children with sleep-disordered breathing. Archives Otolaryngol Head Neck Surgery 2007; 133:974-979.
24. Kumar G, Steer RA. Factor validity of the Conners' parent Rating ScaleRevised: Short form with psychiatric outpatient. J Pers Assess 2003; 80:252259.

25. Parker JD, Bond BJ, Reker DL, Wood LM. Use of Conners-Wells Adolescent Self-Report Scale (Short Form) with children. J Atten Disord 2005; 8:188194.

26. Erhart M, Döpfner M, Ravens-Sieberer U; BELLA study group. Pyshometric properties of two questionnaires: Comparing the Conners' scale and the FBB-HKS in the general population of German children and adolescentsresults of the BELLA study. Eur Child Adolesc Psychiatry 2008; 17:106-115.

27. Gau SS, Soong WT, Chiu YN, Tsai WC. Psychometric properties of the Chineese version of the Conners' parent and teacher rating scales-revised: Short form. J Atten Disord 2006; 9:648-659.

28. Silva RR, Alpert M, Pouget E, Silva V, Trosper S, Reyes K, Dummit S. A rating scale for disruptive behavior disorders, based on the DSM-IV item pool. Psychiatr 0 2005; 76:327-339.

29. Schneider BH, Normand S, Soteras de Toro Mdel P, Santana Gonzalez $Y$ Guilarte Téllez JA, Carbonell Naranjo M, Musle M, Díaz Socarras FJ, Robaey P. Distinguishing features of Cuban children referred for professional help because of ADHD: Looking beyond the symptoms. J Atten Disord 2011; 15:328-337.

30. Ismail WSW, Jaafar NRN, Daud TIM, Shah SA, Ismail A, Shafiee Z.. The association between the attention deficit hyperactivity disorder (ADHD) symptoms and bully/victim problem among Malaysian sixth-graders. Asian J Psychiatr 2010; 11:1-8.

31. Farre-Riba A, Narbona J. Conners Rating Scales in the assessment of attention deficit disorder with hyperactivity (ADHD). A new validation and factor analysis in Spanish children. Rev Neurol 1997; 25:200-204.

32. Dereboy Ç, Şener Ş, Dereboy F, Sertcan Y.Conners Öğretmen Derecelendirme Ölçeği Türkçe Uyarlaması-2. Çocuk ve Gençlik Ruh Sağlığı Dergisi 1997; 4:10-18

33. Dereboy Ç, Şener Ș, Dereboy IF. Conners Anababa Derecelendirme Ölçeği Uyarlama Çalışması. X. Ulusal Psikoloji Kongresi, Ankara; 1998.

34. Dereboy C, Senol S, Sener S, Dereboy F. Conners Kısa Form Öğretmen ve Anababa Derecelendirme Ölçeklerinin Geçerlikleri. Türk Psikiyatri Derg 2007: 17:48-58.

35. Kılıç BG, Sener Ş. Dikkat Eksikliği Hiperaktivite Bozukluğu Alt Gruplarında Conners Öğretmen ve Anababa Ölçeklerinin ayırıcı özellikleri. Çocuk ve Gençlik Ruh Sağlığı Dergisi 2003; 10:50-57.

36. Sener S, Dereboy C, Dereboy F, Sertcan Y. Conners Öğretmen Derecelendirme Ölçeği Türkçe Uyarlaması-1. Çocuk ve Gençlik Ruh Sağlı̆ı Dergisi 1995; 2:131-141

37. Kaner S, Büyüköztürk Ş, İşeri E ve ark. Adaptation study of Revised Conners' Parent Rating Scale-Long Form to Turkish population. 16 th. Congress of National Children' and Adolescent' Mental Health and Diseases, Antalya, Turkey; 2006.

38. Kaner $S$, Büyüköztürk Ş, İșeri E, Ak A, Özaydın L.. Conners Anababa Dereceleme Ölçeği Yenilenmiş Uzun Formu: Faktör yapısı, geçerlik ve güvenirlik çalışması. Çocuk ve Gençlik Ruh Sağlığı Dergisi, 2011; 18:45-58.

39. Kaner S, Büyüköztürk S, Isseri E. Conners Öğretmen Dereceleme ÖlçeğiYenilenmiş Kısa'nın Türkiye Uyarlama Çalışması. Eğitim ve Bilim 2013; 167; 81-97.

40. Kaner S, Büyüköztürk Ş, Iş̧eri E. Conners-Wells Ergen Öz-Bildirim ÖlçeğiKısa'nın Türkiye uyarlama çalışması. Klinik Psikiyatri Dergisi 2012; 15; 208217.

41. Quay HC, Peterson DR. Revised Behavior Problem Checklist. Professional Manual. Odesa: PAR; 1996.

42. Kaner S. Yeniden Değerlendirilmiş Davranıș Problemleri Kontrol Listesinin Ülkemize Uyarlanması. 9. Ulusal Özel Eğitim Kongresi. Eskişehir; 1999.

43. Kaner S, Büyüköztürk Ș. Yenilenmiş Problem Davranış Kontrol Listesi'nin Türk kültürüne Uyarlama Çalışması. Yayınlanmamış araştırma raporu; 2006.

44. Kaner S, Uçak-Çiçekçi A. Gözden Geçirilmiş Davranış Problemleri Kontrol Listesinin Türkçeye Uyarlanması. Özel Eğitim Dergisi 2000; 2: 23-34.

45. Cole DA. Utility of confirmatory factor analysis in test validation research. $J$ Consult Clin Psychol 1987; 55:584-594.

46. Kline P. An easy guide to factor analysis. New York: Routledge; 2000.

47. Stevens J. Appied multivariate statistics for the social science (Third edition). New York: Lawrence Erlbaum Associates; 1996

48. Sümer N. Yapısal eșitlik modelleri: Temel kavramlar ve örnek uygulamalar. Türk Psikoloji Yazıları 2000; 3:49-74 
49. Tabachnick BG, Fidell LS. Using multivariate statistics (4th edition). Boston: Allyn and Bacon; 2001.

50. Anderson JC, Gerbing DW. The effect of sampling error on convergence, improper solutions, and goodness-of-fit indices for maximum likelihood confirmatory factor analysis. Psychometrika 1984; 49:155-173.

51. Kline P. Principles and practice of structural equation modeling: Methodology in the social sciences. The Guilford Press; 2005.

52. Marsh HW, Balla JR, McDonald RP. Goodness-of-fit indexes in confirmatory factor analysis: The effect of sample size. Psychological Bulletin 1988; 103:391-410.

53. Schermelleh-Engel $\mathrm{K}$, Moosbrugger $\mathrm{H}$. Evaluating the fit of structural equation models: tests of significance and descriptive goodness-of-fit measures. Methods of Psychological Research Online 2003; 8:23-74.

54. Hooper D, Coughlan J, Mullen M. Structural equation modeling: Guidance for determining model fit. J Bus Res. 2008; 6:53-60.

55. Şimşek ÖF. Yapısal Eșitlik Modellemesine Giriș. Temel İlkeler ve LiSREL Uygulamaları. Ankara: Ekinoks; 2007.

56. Helton SC, Corwyn RF, Bonner MJ, Brown RT, Mulhern RK. Factor analysis and validity of Conners Parent and Teacher Rating Scales in childhood cancer survivors. J Pediatr Psychol 2006; 31:200-208.

57. Çokluk Ö, Şekercioğlu G, Büyüköztürk Ş. Sosyal Bilimler Için Çok Değişkenli İstatistik. SPSS ve Lisrel uygulamaları. Ankara: Pegem; 2012.

58. Erkuş A. Psikometri Üzerine Yazılar. Ankara: Türk Psikologlar Derneği Yayınlarl; 2003.

59. Şencan H. Sosyal ve Davranışsal Ölçümlerde Güvenirlik ve Geçerlik. Ankara: Seckin Yayınları; 2008

60. Bird HR, Gould MS, Staghezza-Jaramillo BM. The comorbidity of ADHD in a community sample of children aged 6 through 16 years. J Child Fam Stud 1994; 3:363-378.

61. Coolidge FL, Thede LL, Young SE. Heritability and the comorbidity of attention deficit hyperactivity disorder with behavioral disorders and executive function deficits: A preliminary investigation. Dev Neuropsychol 2000; 17:273-287.

62. Kadesjö B, Gilberg C. The comorbidity of ADHD in the general population of Swedish school-age children. J Child Psychol Psychiatry 2001; 42:487-492.

63. Souza I, Pinheiro MA, Denardin D, Mattos P, Rohde LA. AttentionDeficit/Hyperactivity Disorder and comdrbidity in Brazil comparisons between two referred samples. Eur Child Adolesc Psychiatry 2004; 13:243-248.
64. Achenbach TM, Dumenci L, Rescria LA. Ten-year comparison of problems and competencies for national samples of youth: Self, parent, and teacher reports. J Emot Behav Disord 2002; 10:194-203.

65. Becker A, Hagenberg N, Roessner V, Woerner W, Rothenberger A Evaluation of the self-reported SDQ in a clinical setting: Do self-report tell us more than ratings by adult informants? Eur Child Adolesc Psychiatry. 2004: 13:17-24.

66. Kaner S. ADHD Symptoms in national samples of Turkish adolescents: Self, parent, and teacher reports. Procedia Social and Behavioral Sciences 2011; 15:3342-3348

67. Achenbach TM, McConaughy SH, Howell C T. Child/adolescent behavioral and emotional problems: Implications of cross-informant correlations for situational specificy. Psychol Bull 1987; 101:212-232.

68. De Los Reyes A, Kazdin AE. Informant discrepancies in the assessment of childhood psychopathology: A critical review, theoretical framework, and recommendations for further study. Psychol Bull 2005; 131:483-509.

69. Gomez R. Australian parent and teacher ratings of DSM-IV ADHD symptoms: Differential symptoms functioning and parent-teacher agreement and differences. J Atten Disord 2007; 119:17-27.

70. Kaner S. Zihin engelli çocukların duygusal ve davranışsal problemlerinin değerlendirilmesinde anababa ve öğretmen tutarllığı. Ankara Üniversitesi Eğitim Bilimleri Dergisi 2009; 42: 239-263.

71. Kolko DJ, Kazdin AE. Emotional/behavioral problems in clinical and nonclinical children: Correspondence among child, parent, and teacher reports. J Child Psychol Psychiatry 1993; 34:991-1006.

72. McConaughy SH. Advances in empirically based assessement of children's behavioral and emotional problems. School Psych Rev 1993; 22:285-307.

73. Renk K. Cross-informant ratings of behavior of children and adolescents: The "gold stardart". J Child Fam Stud 2005; 14:457-468.

74. Smith SR. Making sense of multiple informants in child and adoliscent psychopathology. J Psychoeduc Assess 2007; 25:139-149.

75. Büyüköztürk S, Akgün Ö, Karadeniz Ș, Demirel F, Kılıç E. Bilimsel Araştırma Yöntemleri. Ankara: Pegem; 2008.

76. Hovardaoğlu S. Davranış Bilimleri İçin Araştırma Teknikleri. Ankara: Hatipoğlu Yayınları; 2007. 
Reproduced with permission of the copyright owner. Further reproduction prohibited without permission. 